\title{
BUDISMO, OCIDENTE, LÉVI-STRAUSS E SLAVOJ ZIZEK
}

\author{
Antônio Carlos de Madalena Genz
}

\begin{abstract}
Resumo: Através de pesquisa de campo realizada no ano de 2004, o artigo procura analisar o processo de desenvolvimento do budismo no Brasil, sua apropriação e ressignificação a partir da prática e entendimento por brasileiros sem ligação anterior com esta religião. A análise se desenvolve tendo como parâmetros, ou referenciais, em pólos opostos de um espectro, a evocação enaltecida de Buda, feita por LéviStrauss, nas páginas finais de Tristes trópicos, e a posição de Slavoj Zizek, que vê as religiōes, na cena atual, como instrumentos à busca pós-moderna de prazer.
\end{abstract}

Palavras-chave: Budismo - Zen - Identidade

Abstract: Based on a fieldwork realized during the year 2004, this paper intents to analyze the development of Buddhism in Brazil, its appropriation and meaning, from a stand point of its practice and understanding by Brazilians without prior links or exposure to this Religion. The analysis develops taking as parameters, or referential, as opposed poles of a specter, the exalted evocation of Buda made by Lévi-Strauss in the final pages of his Tristes tropiques and, the position of Slavoj Zizek, considering the Religions, in the present scenario, as instruments of the post-modern search for pleasure.

Keywords: Buddhism - Zen - Identity.

De início, quero declarar que o título, com sua referência aos pensadores citados e a relação entre uma religião e uma parte da geografia do mundo, não guarda nada de pretensioso. Minha intenção é bem mais simples. A de fazer uma reflexão sobre o budismo no Brasil a partir da minha pesquisa de campo em uma comunidade zen e a dissertação de mestrado resultante dela. Como a pesquisa de campo foi feita junto ao Via Zen, na cidade de

Mestre em Antropologia Social pela Universidade Federal do Rio Grande do Sul-UFRGS.

Debates do Ner, Porto Alegre, ano 7, n. 9, p. 109-128, jan./Jun. 2006 
Porto Alegre, no ano de 2004, já iniciarei o segundo parágrafo com uma brutal, e salutar, redução de foco. ${ }^{1}$ Do Ocidente para Porto Alegre!

Tive a boa fortuna de fazer minha pesquisa com a presença do mestre zen japonês, Moriyama Roshi, vivendo no Via Zen. Em março de 2005 ele retornou ao Japão, ao que parece fechando o seu ciclo de moradia no Brasil. Meu trabalho de campo se encerrou com a etnografia da conferência $O$ budismo brasileiro durante o Fórum Social Mundial (FSM), em janeiro de 2005. Surpreendeu-me ver, em um encontro assistido em sua maioria por simpatizantes ou praticantes budistas, um dos palestrantes trazer para a cena um artigo acadêmico sobre o budismo, que eu acabara de ler há uma semana. Considerei um lance de sorte poder estar ali presente e ver o artigo de Frank Usarski, $O$ dharma verde-amarelo mal-sucedido: um esboço da acanhada situação do budismo ser referenciado e contraposto. Basicamente, tudo que se segue tem relação com o trabalho de campo no Via Zen e a observação da conferência no FSM.

Antes de colocar a mão na massa, uma última contextualização tem que ser feita. Do por que dos nomes de Lévi-Strauss e Zizek no título. Começando pelo último, Zizek em um pequeno artigo vê o Dalai Lama como exemplar da atitude do que ele denomina de hedonismo espiritualista:

Ao invés de procurar redimir o núcleo puramente ético de uma religião contra as suas instrumentalizaçóes políticas, seria necessário criticar implacavelmente o próprio núcleo - em todas as religiōes. Hoje, quando as próprias religiōes (da espiritualidade New Age ao fácil hedonismo espiritualista do Dalai Lama) estão mais do que prontas a servir a busca pós-moderna do prazer, paradoxalmente, somente um materialismo coerente é capaz de sustentar uma posição ética militante verdadeiramente ascética.(Zizek, 2004, p. 25)

O artigo de Zizek foi uma espécie de constante dilema para mim, du-

\footnotetext{
${ }^{1}$ Dissertação de mestrado "A música silenciosa do Darma: um estudo antropológico das práticas e representaçōes de uma comunida de zen budista em Porto Alegre" (Madalena Genz, 2005), orientada pelo prof. Dr. Carlos Alberto Steil.
}

Debates do NER, Porto Alegre, ano 7, n. 9, p. 109-128, Jan./Jun. 2006 
rante a pesquisa. Embora não concordando com ele em sua idéia geral, muitas vezes me senti tendo que dar o braço a torcer. Seu diagnóstico parecia não estar de todo errado. No caso específico, muitas vezes tive a impressão de que o budismo se conforma (no sentido de tomar a forma) à busca de que Zizek fala.

E Lévi-Strauss porque não há como não me reportar ao viajante que, ao final do itinerário, refletindo sobre seu percurso, produziu algumas das páginas mais marcantes não apenas da antropologia, mas da literatura que se escreveu no século XX. O último capítulo de Tristes trópicos é permeado pela evocação da figura de Buda. A partir da imagem do sábio ao pé da árvore, Claude Lévi-Strauss apresenta uma espécie de contraponto à experiência histórica ocidental. São páginas tocantes porque escritas a partir da subjetividade com a qual Lévi-Strauss assume a herança que é sua intelectualmente, a história do Ocidente.

$\mathrm{Na}$ verdade, que mais aprendi com os mestres que escutei, com os filósofos que li, com as sociedades que visitei e com essa própria ciência da qual o Ocidente se orgulha, senão fragmentos de lições que, unidos uns aos outros, reconstituem a meditação do Sábio ao pé da árvore? Todo esforço para compreender destrói o objeto a que estávamos ligados, em benefício de um esforço que o suprime em benefício de um terceiro, e assim por diante, até chegarmos à única presença durável, que é esta em que desaparece a distinção entre o sentido e a ausência de sentido: a mesma de onde partíramos. Já se vão 2500 anos que os homens descobriram e formularam essas verdades. Desde então, nada descobrimos, a não ser - experimentando, após outros, todas as portas de saída - outras tantas demonstraçōes suplementares da conclusão de que gostaríamos de escapar. (Lévi-Strauss, 1996, p.389)

É um texto forte, onde se destaca o valor com que o autor estabelece o ensinamento de Buda na história humana. Geertz, ao analisar o livro, o vê como um tratado reformista. "Já houve um imenso número de acusaçôes ao Ocidente por seu impacto no não-Ocidente, mas poucas, por mais radicais que sejam seus autores, têm a amargura e a força devastadoras do Tristes trópicos de Lévi-Strauss" (Geertz, 2002, p. 58) 
Do texto de Lévi-Strauss às palavras de Zizek eu tinha a experiência de campo pela frente para ver o que era e onde estava o budismo brasileiro. Uma parte dele, pelo menos.

\section{O VIA ZEN, MESTRE MORIYAMA E OS PRATICANTES}

O Via Zen era orientado espiritualmente por Moriyama Roshi. Residindo em Porto Alegre desde o ano 2000, veio ao Brasil, em 1993, enviado pela Sotoshu, organização que dirige a escola Soto Zen, para assumir a função de superior junto ao templo Busshinji, na cidade de São Paulo. Quando chega a esta cidade, já traz em sua biografia experiência nos Estados Unidos, assim como a construção do mosteiro Zuigakuin International Zen Temple, no Japão, voltado ao propósito de proporcionar um ambiente acolhedor aos estrangeiros que queriam praticar o zen no Japão. E havia fundado na França o Hokaiji International Zen Temple.

Sua atividade de professor e transmissor do zen sempre foi pautada pelo interesse em tornar disponível a prática para pessoas que não têm experiência anterior no budismo. Sua proposta principal no Via Zen é a de desenvolver, ou pelo menos ajudar, a criação de um budismo brasileiro. Como ele mesmo afirma,

O Brasil necessita de um budismo brasileiro, não do budismo japonês. Cada país tem suas próprias características. Vocês criam um novo budismo. O Brasil criará um budismo próprio. De outra forma seria imitação. Imitação não é cultura. Penso que o mesmo deva acontecer com o budismo tibetano, por exemplo.Deve surgir um genuinamente brasileiro. (Moriyama Roshi, 2001, p. 86)

Um dos seus discípulos, Giovanni, me informa que:

O interessante em se estudar o zen com o Roshi é que o ensinamento dele nos é dado realmente de mente-a-mente. Ele só me disse aquela única frase, mas todo o resto estava dito ali, não foi algo que eu inventei. Ele fala com o seu corpo. 
A questão que surge aqui é a da tensão e negociação entre um conhecimento que é basicamente prático e centrado no corpo e o processo de assimilação do mesmo por ocidentais, que têm hábitos culturais distantes desse tipo de experiência, fruto de uma cultura onde corpo e mente são duas entidades separadas e, principalmente, ao fato de em nossa tradição cultural conhecer alguma coisa é assimilá-la mentalmente.

O zen prima pela contenção e silêncio, pela experiência fundada no corpo. Além disso, a meditação é feita com os praticantes de costas uns para os outros, cada um voltado para a parede. Como me disse Maria Eugênia, uma das praticantes:

Tem toda uma questão no zen que é a nossa atitude corporal, existe uma energia que se desenvolve nessa parte. O Roshi falou sobre postura e eu como discípula pensei, 'poxa, não vejo a hora de dar um toque nas pessoas', mas eu sei que a gente vai ter a oportunidade, isso acontece. (...) A gente tem que ir exercitando. Mas, por que que eu fiz esse comentário? No sentido que as pessoas, às vezes, não sabem. Elas estão sentadas no zendo, fazendo zazen, aí não faz certo, não está fazendo exatamente o zazen porque a mente está muito ocupada, não está com a respiração, o foco no objeto da tua meditação que é a nossa respiração. Então, aí a energia não se desenvolve fácil.

- Tu consegues observar isso vendo a postura da pessoa?

- Sim, a gente observa. Eu não fico olhando para os outros quando estou fazendo o meu zazen, mas eu sinto. Eu também sinto se alguém está muito mole, muito frouxo. Também existe uma idéia assim das pessoas que vêm para o zen, que pensam que zen é relaxar ou ficar numa "nice", numa boa e não é.

A respeito das características do zen, um outro entrevistado, Ricker, é taxativo:

$\mathrm{O}$ zen não é sedutor. $\mathrm{O}$ zen, tu conhece, entra lá, senta, medita e depois vai embora. Enquanto que no budismo tibetano, ele é todo escalonado. Ele é construído. Por exemplo, se tu fizeres uma doação pecuniária, essa doação

Debates do NER, Porto Alegre, Ano 7, n. 9, P. 109-128, JAn./Jun. 2006 
vai te retornar em méritos, existe toda uma educação e no zen é complicada essa coisa e muitas pessoas da contracultura também não tinham poder aquisitivo.

Ricker estabelece um paralelo entre a atração pelo zen e a contracultura.

O zen sempre foi, do meu ponto de vista, contracultural,... eu vi muita gente nesses dez anos de zen-budismo, eu vi muita gente que já tinha tentado todas as terapias, todos os caminhos alternativos e só encontraram refúgio ali.

A questão da contracultura é um ponto importante na relação com o zen. É através desse movimento por novos valores, e no campo religioso a busca de uma nova forma de espiritualidade, que vai crescer decisivamente a difusão mais ampla do budismo e especificamente do zen no Ocidente.

Segundo Carozzi (1999), a Nova Era combina em seu discurso e prática, como metas de mudança, a transformação individual com a sacralização do self, a espiritualidade, e rejeição dos marcos institucionais ocidentais. Conseqüência disso, o Oriente é estereotipado e mistificado. Ele é o outro no espelho do Ocidente e portanto, um produto idealizado do imaginário ocidental. Assim, no zen, além da questão de adaptação a uma disciplina de aprendizado que é fundada no corpo, existe também, para os ocidentais, o processo de passagem para a visão de um religião como de fato ela é, com suas exigências e prescrições, ou seja, a religião em sua dimensão concreta e não mais apenas idealizada.

Com sua forte ênfase na experiência pessoal, acrescendo-se a isso o sentido de respeito pelo universo e natureza, o budismo se enquadraria dentro do quadro que Steil sublinha:

A experiência religiosa hoje parece apontar para um processo de recuperação dos sentidos como linguagem significativa. O conflito entre emoção e razão que perpassa a experiência moderna no Ocidente, parece dar lugar a uma nova relação onde razão e coração andam juntos. Não se trata de escolher entre o dogma e a experiência, mas de buscar a autenticidade afetiva nas vivências espirituais incorporadas nas trajetórias pessoais. (Steil, 2001, p. 124)

Debates do NER, Porto Alegre, Ano 7, n. 9, P. 109-128, Jan./Jun. 2006 
Como dimensões ou características gerais das modernas formas de crer, Oro (1997) destaca: $1^{\circ}$ ) a dimensão emocional que seria marcada pela experiência pessoal, autenticidade afetiva e engajamento total do corpo e dos sentidos na expressão religiosa; $2^{\circ}$ ) tendência em incorporar, integrar e juntar ao invés de restringir e separar; $3^{\circ}$ ) uma dimensão terapêutica, em que o espiritual se associa com saúde, equilíbrio psíquico e bem-estar geral.

As três características apontadas como gerais em relaçáo ao novo campo religioso se aplicamintegral menteao budismo. Experiênciapessoal, engajamento do corpo, tendência integrativa ao invés de dissociativa, e a idéia de cura, por exemplo, enfatizada por Ricker, quando compara o zen a uma farmácia.

Eu diria que a religião é um remédio que tu precisa tomar, e o zen é uma farmácia que fica ali vendendo, mas a idéia é que ninguém precise mais tomar remédio, todo mundo tem seu caminho decidido internamente. $\mathrm{O}$ zen é fantástico na minha vida porque ele me mostra isso.

O interessante é que esses aspectos apontados por Steil e Oro se manifestam de forma tão clara nos depoimentos colhidos, que conforme acima, vemos uma associação entre as idéias de religião e remédio e, como uma conseqüência, a do zen a uma drogaria moderna. Muitos pesquisadores têm salientado o aspecto pragmático do budismo, que fica claro aqui. Mas mais que isso, gostaria de chamar a atenção que por um mecanismo de dissociação, fusão ou mistura de campos semânticos, o que ocorre é que o zen deixa de ser visto como uma religião. Uma das minhas entrevistadas no Via Zen, Ana Lúcia, me responde que sua religião é a vida.

- A minha religião é a vida, não tenho religião, porque que tu tem que ter uma religião formal, eu acho que ser religioso não significa abraçar uma religião.

- Mas tu não está numa religião vindo aqui praticar com um mestre budista?

-Sim e não. É tipo assim, mais ou menos.... tu precisa at ravessar um rio, tem que usar um meio para chegar lá do outro lado e eu acho que o budismo é um meio, é uma maneira de se chegar lá.

Debates do NER, Porto Alegre, Ano 7, N. 9, P. 109-128, Jan./Jun. 2006 
- Mas tu não tá atravessando com essa canoa do budismo?

- (risos) Sim... e não

(...)

- Talvez porque eu não considere o catolicismo uma religião, mas um dado da minha pessoa, da minha identidade civil, então na verdade para mim é apenas um dado. Agora em termos de religião, a vida, nenhuma. Eu insisto nisso porque eu não pretendo sair de uma gaiola e entrar em outra, por mais bonita que a outra seja. Eu prefiro sair de todas as gaiolas!

O que é interessante é que, embora Ana Lúcia veja o catolicismo da mesma maneira como vê o seu número de registro na carteira de identidade, é, ainda assim, através da noção de religião vinculadaa pertença originária ao catolicismo, que vai conduzi-la ao processo de não enxergar o que faz no Via Zen como algo ligado ao conceito de religião.

No Via Zen encontrei um conjunto de pessoas que se dividiam em dois grupos. Um que identificava o que fazia com u ma religião - o zen, o budismo - e outras que não faziam essa identificação. Mas como um denominador comum a ambos os recortes o fato unânime de verem aquilo como um caminho espiritual.

Maria Eugênia, uma das minhas entrevistadas, deixa isso claro quando afirma em relação ao budismo:

Ali eu encontrei as coisas ditas como elas realmente são. $\mathrm{O}$ aspecto das emoções, das nossas emoções aflitivas. Eu antes não tinha encontrado, alguém dizia assim raiva, o que que é? E porque a gente deve, a gente pode dissolver, a gente pode superar estes estados aflitivos da nossa mente. E a gente tem uma responsabilidade, não só conosco mesmos, mas com o ambiente que nos rodeia, todas as pessoas que nos rodeiam.

Vivemos um momento histórico caracterizado pela descrença no poder das ideologias e da possibilidade de grandes narrativas. Mais que isso, no plano coletivo, a própria idéia de utopia se encontra num momento de baixa, procurando ser rearticulada em novos modelos de ação social. Esse 
momento histórico reforça ainda mais a busca por soluções num plano individual. E é nesse plano que a opção, no campo religioso, pelo budismo pode ser entendida. Ela é marcada por esse crivo da autonomia individual. O budismo no Brasil é fruto daquilo que Oro (1997) apontou como sendo a ação da modernização levando a uma diversificação do campo religioso, com o direito por parte dos sujeitos de escolha religiosa, de fazer suas opçôes de sentido, de construir seu universo simbólico.

Como forma de religiosidade, o budismo permite aos seus adeptos exercer uma experiência que se coadunacom suas exigências enquantoindivíduos, naquele contexto que Oro (1997) aponta como formas modernas de crer: o de uma experiência pessoal, marcada pela autenticidade. E ao invés de separar, a possibilidade de integrar e juntar, ambas propiciadas pelo budismo. E nesse aspecto, vale ressaltar que o budismo se abre como uma espécie de holismo no qual toda a experiênáa do sujeito e sua visão de mundo podem ser assimiladas e interpretadas a partir de uma chave cognitiva que esta religiāo traz em si, em seus conceitos basilares e naquilo que se denomina de caminho óctuplo. Ao invés de compartimentalizar sua experiência em diferentes esferas, em gavetas classificatórias, o budismo permitiria um senso de individualidade marcado pela integração com o universo. Uma forma de experiência religiosa que sacraliza o todo, justamentepor que não distingue um plano sagrado de outro profano. A idéia de não existência de um eu, aliada a noção de interdependência são fundamentais aqui, determinando as coordenadas para uma ação ética no seu agir no mundo. Nesse sentido o budismo traria um elemento de reflexividade que iria ao encontro de um dos traços do que Giddens (2002) define como marcas do nosso momento histórico, a reflexividade dos processos de vida e do próprio sujeito.

\section{O BUDISMO BRASILEIRO (FSM) E A QUESTÃO DA IDENTIDADE BUDISTA}

Teço aqui algumas reflexões sobre a questão da identidade budista. Os dados etnográficos me mostraram a dificuldade, muitas vezes, de pratican-

Debates do Ner, Porto Alegre, Ano 7, n. 9, p. 109-128, jan./Jun. 2006 
tes inseridos no Via Zen se autodenominarem budistas. A dificuldade está sem dúvida ligada a um traço central do cânone budista, aquele que diz respeito à não existência substancial do eu. Assim, afirmar-se budista pareceria contradizer-se com a doutrina, uma vez que na prática um budista se empenha em se liberar do ego, visto como originador de considerável parte do sofrimento que experimentamos na vida. Esse paroxismo, notei em campo, era algumas vezes sutilmente contornado pela resposta "sou um praticante". O acréscimo de mais um verbo, com o sentido de alguma coisa que se está exercitando tem um efeito de deslocamento e ao mesmo tempo abranda a força que o pronome pessoal e o verbo "ser" teriam numa resposta simples e objetiva como "Eu sou".

A oficina "Budismo brasileiro" ocorri da em janeiro de 2005, dentro da programação do $5^{\circ}$ Fórum Social Mundial, tendo como palestrantes Moriyama Roshi, Lama Santen, Monja Coen e Petrúcio Chalegre, representantes do budismo no Brasil, se revelou uma ótima caixa de ressonância para analisar e pensar essa questão.

Petrúcio Chalegre, o primeiro a ter a palavra, para minha surpresa iniciou sua fala e usou parte significativa do seu tempo referindo-se ao artigo de Usarski (2004).

No ensaio $\mathrm{O}$ dharma verde-amarelo mal-sucedido - um esboço da acanhada situação do budismo, Frank Usarski contrasta o fato de o budismo ter se tornado um fenômeno de mídia no Brasil, uma religião em moda e da moda, por um lado, e de outro, o fato de os dados comparativos dos dois últimos censos do IBGE mostrarem que houve uma diminuição do número de budistas no país.

Petrúcio Chalegreé consultor empresariale professorde darma da Sanga Zen Budista de Florianópolis, onde reside. $\mathrm{O}$ apresentador destacou o fato dele ter 30 anos de experiência no estudo e prática do budismo. De todos que formavam a mesa do painel ele era aquele que falava de modo mais erudito. Iniciou levantando a questão de para onde vai o budismo brasileiro? Quais seriam seus caminhos? A partir daí perpassou rapidamente um pouco da história da difusão do budismo desde sua origem na Índia, destacando como característica marcante em todo esse processo que "o budismo, 
de país a país, tomou a forma desse país". Ou seja, se enraizou em cada lugar a partir de uma abertura para a cultura local. Afirmou também que o budismo ocidental hoje é diferente do budismo oriental. Que mantém a mesma doutrina, mas suas formas são diferentes. Assim, concluiu essa parte afirmando que o budismo tem a propriedade de vestir várias roupagens. ${ }^{2}$

A partir dessa constatação, Chalegre afirmou, com ênfase, que "noBrasil o que salta aos olhos é a conduta do praticante. No ocidente os leigos tornaram-se algo monges e os monges algo leigos." Cita como exemplo de invenções puramente ocidentais o Via Zen e o Centro de Estudos Budistas (CEB), este último ligado ao Lama Padma Santen.

A partir daí ele apresenta o artigo de Usarski, enfatizando a questão do censo com a diminuição dos budistas no país. Isto serve para preparar a questão que ele apresenta, de por que diminuiu o número de budistas. Chalegre procura responder isso através de dois argumentos. Um, o da morte dos budistas de migração. E o principal, ligado aos budistas de conversão, de que o budismo não tem ritual de iniciação como o batismo, na Igreja Católica.

Chalegre procurou relativizar e contestar os dados do IBGE, no sentido de mostrar que, de um ponto de vista budista, eles têm muito pouco valor. Argumentos nesse sentido, numa espiral crescente em sua fala, são a de que o budismo está entrando na cultura ocidental e brasileira de uma maneira "calma, tranqüila, sem pressa", ou seja, no que se poderia denominar de estilo budista. Ilustrou com uma propaganda em exibição na televisão àquela época, em que um monge budista aceita com resignação e compaixão uma série de percalços no seu itinerário pela cidade e que finaliza com o mesmo dando tapas em um computador devido à dificuldade e demora em se conectar à internet. ${ }^{3}$ É um exemplo, segundo ele, de que o budismo já penetrou no imaginário brasileiro.

Finalizou então sua argumentação com uma crítica aos métodos do censo. Basicamente de que o budismo é um fenômeno qualitativo e que o

\footnotetext{
${ }^{2}$ Ele não explicitou, mas o sentido de sua argumentação seria o de usar o termo 'roupagens' para se referir às características culturais de cada país.

${ }^{3}$ A propaganda é de uma companhia de serviços de conecção à rede da internet.
} 
censo faz um apanhado quantitativo, uma amostra que tem mais a ver com parâmetros de mercado. E o budismo não têm objetivos mercadológicos, de fazer adesões. Por fim, sintetiza de que o budismo lida com a identidade pessoal de cada um, procurando desconstruir os papéis ligados ao ego e assim não quer que as pessoas coloquem mais um rótulo em si mesmas. Um argumento que eu encontrei em campo na minha pesquisa, e que nos inclinaria a pensar que o budismo para muitos dos seus praticantes é uma religião em que dizer-se budista é quase entrar em contradição com a mesma!

Pensoque o argumento de Chalegre, de uma incomensurabilidade entre o budismo e o censo, mais que um exagero, pode estar mostrando uma certa mitificação que budistas ou a comunidade budista é passível de fazer de si mesma. Talvez em função da questão do eu nessa doutrina, isso os conduziria a se colocar num plano acima daquele das classificaçóes e que se expressaria no que eu denomino de uma comunidade etérea. Essa denominação me ocorreu a partir da tentativa, que se revelou frustrada, de trabalhar com o par de conceitos de Elias, os estabelecidos e os outsiders, para abordar o budismo. Esse par de conceitos que se funda em um contexto relacional se mostrou infrutífero em campo. Em função da noção budista de interdependência de todos os fenômenos, seus praticantes se abririam para uma espécie de holismo. A contraparte desse holismo programático que encontrei em campo foi a dificuldade, ou mesmo uma barreira, de se criar um espaço institucional de crítica e debates.

O segundo a falar foi Lama Santen, figura de destaque na cena budista, ligado ao Mosteiro de Três Coroas, onde foi ordenado lama na tradição do budismo tibetano, e que atualmente dirige uma sanga própria em Viamão. ${ }^{4}$ Sua comunicação teve como foco a figura do Dalai Lama, para explicitar a situação do budismo no Ocidente e, por conseqüência, no Brasil.

Santen chamou a atenção para o fato de que se alguém ler os primeiros trabalhos escritos pelo Dalai Lama quando se fixou no Ocidente, no início dos anos 70, e os livros mais recentes, verá que há uma grande transforma-

${ }^{4}$ Ver Alves, 2004, que desenvolveu trabalho nessa comunidade. 
ção. Se considerarmos isso como duas fases distintas, segundo Santen, antes o Dalai Lama usava "palavras complicadas" e hoje não. Enquan to antes ele procurava apresentar o conteúdo do budismo ao Ocidente, hoje ele passou a falar em termos de se ter um bom coração. A partir da noção de compaixão, o Dalai Lama teria transformado sua linguagem de forma a encontrar uma forma de fazer o budismo assimilável à mentalidade ocidental sem o uso de termos técnicos budistas.

A mudança no discurso do Dalai Lama seria indicadora, segundo Santen, de que temos hoje, tanto no Oriente quanto no Ocidente, um novo budismo. "É um novo budismo, aqui e lâ", segundo suas palavras. Em relação a isso podemos considerar duas coisas. Primeira que, em relação ao Ocidente, é novo no sentido de que, excetuando as comunidades de origem étnica, não havia praticantes ocidentais e, principalmente, mestres budistas desenvolvendo esses ensinamentos para esse público. Em relação ao Oriente, alguns pontos merecem análise. Lama Santen não especificou, mas provavelmente, por estar vinculado ao budismo tibetano e estar falando do Dalai Lama, estivesse se referindo especificamente ao budismo tibetano. Que de fato se transformou por ser hoje uma "religião no exílio". Uma série de questôes poderiam ser levantadas, como por exemplo os processos de transformação rápida de países orientais sob o empuxo dos valores de industrialização, secularização e modernização, onde os padrões materialistas ocidentais passam a ser implantados e, valorizados, exercendo uma forte atração, principalmente sobre os jovens. De qualquer forma, esse não é o tema de nossa análise.

Lama Santen destacou que na história do budismo essa religião sempre viveuum processo de misturar a essência budista, uma visãoatemporal,com as formasculturaisonde penetrava.Assim,segundosuas palavras, o budismosempre "chacoalhou as culturas an tigas" e hoje se defronta com a cultura contemporânea modema, num diálogo entre esta visão atemporal e estas culturas.

Uma das conseqüências da mudança de linguagem do Dalai Lama é que ele se transformou num best-seller. Seus livros são editados com grande sucesso de vendas em vários países. Além dos livros do Dalai Lama, o mercado editorial publica em ritmo crescente grande número de livros budistas 
ou sobre o budismo. Essas obras muitas vezes apresentam um caráter que permite colocá-las na categoria de auto-ajuda e, uma hipótese que se pode lançar com considerável margem de segurança, a partir dos dados do IBGE contrapostos ao sucesso de vendas, é que elas não são lidas apenas por budistas, mas por um universo mais amplo de pessoas.

Curiosamente aquele dos painelistas que mais poderia abordar a questão das diferençasentre o budismo ocidental e oriental (um tópico enfatizado pelos dois painelistas acima citados), Moriyama Roshi, uma vez que é japonês e com larga experiência no Ocidente, foi o último a falar, quando a platéia já estava de certa forma exausta, sob uma tenda debaixo do forte calor do verão porto-alegrense. Assim, Moriyama foi breve, não mais que louvando as qualidades dos praticantes brasileiros e sua satisfação em estar (àquela época) por aqui.

Assim, antes do Roshi, a palavra coube a Monja Coen, ou melhor a oportunidade de uma performance. Monja Coen dirige uma sanga de leigos em São Paulo, após ter se afastado da direção do templo Busshinji em São Paulo, em 2000. Ela fez sua formação nos Estados Unidos e no Japão, voltando ao Brasil em 1996 para assumir o referido templo.

Monja Coen não falou sobre o tema proposto. De certa forma sua participação foi uma performance, cujo clímax foi a prática de meditação que dirigiu durante aproximadamente uns cinco minutos. Ela falou sobre as virtudes do modo de ser budista estabelecendo-o como contraponto à cultura da violência, que é pelo que entendi, a cultura do mundo atual, o modo como vivemos. Assim ressaltou, do ponto de vista budista, que todos estamos ligados, que somos interdependentes, etc. Sua atuação foi bastante performática, falando em um tom de voz como se estivesse fazendo um workshop introduzindo as pessoas na cosmovisão budista e na prática da meditação. $\mathrm{O}$ irônico, em relação a esse discurso de paz e interdependência de todos os seres, foi a justificativa que forneceu ao fato de ter chegado ao compromisso em que era uma das protagonistas com praticamente uma hora e meia de atraso.

Ela afirmou que estava hospedada na casa de amigas que queriam ir ver o presidente Lula, que se apresentava no mesmo dia às 9 horas em um 
ginásio de esportes próximo. Disse que veio a pé de lá até a tenda onde estávamos (que fica no Parque Harmonia, adjacente ao local onde está o ginásio) e que ficava longe. Coincidentemente, eu havia feito o mesmo caminho. Deixara meu carro no estacionamento do ginásio e caminhei até a tenda. Num passo tranqüilo, levei dez minutos. Ao final de sua fala perguntei a um conhecido que estava sentado ao meu lado se a justificativa dela o tinha convencido, e ele disse não. Destaco isso pois me parece contraditório alguém enaltecer a interligação entre todos os seres, falar em uma cultura de paz e respeito e justificar o atraso a um compromisso previamente marcado, no qual se constituía em um dos personagens centrais, com uma razão tão inconsistente que me pareceu, na prática, se não desrespeito, falta de consideração com o público e os demais painelistas. Além do que o bom e velho pedido de desculpas, ocidental que seja, é ainda alguma coisa simples e prática. E ainda guarda seus efeitos práticos, não parecendo ter se tornado uma mera convenção social.

$\mathrm{O}$ atraso e a inconsistente justificativa foram apresentados e absorvidos com tanta naturalidadeque lanço a hipótese de que realmente em termos budistas, eles não têm maior importância. Eles são absorvidos e diluídos dentro dessa visão do budismo, conforme Usarski, oferecida pela mídia e, me parece, endossada por monja Cohen. Um posicionamento hiperbólico dessa religião, em que ela se apresentaria acima das críticas. Afinal, que importância tem o atraso se, quando a monja finalmente chega, sua participação traz algo tão valioso quanto a meditação? Monja Cohen parece assinalar, performaticamente, que o budismo tem o remédio para os males da civilização contemporânea. Ao mesmo tempo em que o budismo não entra em conflito com outras religiōes, por um princípio de respeito às diferenças, parece haver um mecanismo sutil, ligado à idéia dele não como uma religião, mas como um método e, portanto, um remédio eficaz, que o coloca acima das outras religiôes.

Se Usarski problematizou o contraste dos dados do censo com a imagem projetada pela mídia, e essa já é uma questão relevante do ponto de vista de análise, há uma outra que se apresenta bastante mais complexa. Principalmente, num futuro próximo, supondo o crescimento do budismo

Debates do NER, Porto Alegre, Ano 7, n. 9, P. 109-128, jan./Jun. 2006 
no país. Ela diz respeito a uma ambigüidade do budismo, tanto do ponto de vista da sua recepção por ocidentais, no caso brasileiros, quanto, principalmente, a imagem que dela projetam aqueles que são os seus líderes. Por parte desses a metáfora do budismo como um remédio (metáfora forte, pois que tem origem em falas do Buda) permite que o budismo seja visto, ao mesmo tempo, como religião, filosofia de vida, psicologia ou caminho espiritual, abrindo-se no campo religioso como uma espécie de self-service em que o cliente define a opção. Se, como meus dados mostraram, existem pessoas fortemente ligadas a um centro de prática budista, que não vêem o que fazem como religião, mas como um caminho espiritual, do outro lado do espectro podemos supor pessoas que, à indagação de um censo, responderiam não possuir uma religião e que de fato não pertenceriam a um centro ou templo budista. Mas que, caso lhes fosse apresentada uma questão sobre qual é sua filosofia de vida, poderiam responder que sua filosofia de vida é o budismo.

Jurandir Freire Costa (2001) em um interessante artigo, combate a visão reducionista da religião, presente em Freud e assumida por Zizek. Classifica a noção que este último tem das doutrinas budista e taoísta como uma simplificação esquelética. Costa procura recuperar uma dimensão cognitiva da experiência religiosa. Enfim, contesta a idéia da psicanálise de que a espiritualidade é sempre outra coisa do que aquilo que aparenta ser. Restitui à religião sua dimensão de uma visão de mundo, ao invés de um erro cognitivo ou um desvio afetivo.

De acordo com Costa (2001) é possível ver que o enquadramento do Dalai Lama feito por Zizek é fruto dessa concepção reducionista da religião. Apesar disso, no entanto, considero que há algo de verdade no que Zizek diz em relação as religiôes servirem à busca pós-moderna de prazer. E acho que o budismo, em especial, é passível de correr esse risco. Diria que esse risco se originaria da confluência de dois fatores. Um deles, a dificuldade de praticantes budistas assumirem uma identidade definida. $\mathrm{O}$ outro fator, e que na minha opinião alimenta o primeiro, é que os próprios líderes ou professores parecem incentivar esse aspecto. Não tanto em função da doutrina (que fala do não-eu) mas em função da postura que apresenta o 
budismo como uma espécie de panacéia universal, remédio infalível... E aqui toco num ponto que, me parece, poderia ser por si só uma questão para uma análise específica. Em relação à doutrina do não-eu, embora ela seja explicitamente cristalina no budismo, apenas para ficar nas religióes semíticas, todas elas, cristianismo, judaísmo e islamismo também nos falam que não somos aquilo que aparentamos ser, a personalidade. Portanto, nada de novo sob o Sol, como já proclamava o Eclesiastes. E, assim sendo, a idéia de remédio universal trazida pelos líderes parece guardar um nítido sabor mitificador, um bom elemento para alimentaro narcisismocarismático dos mesmos, no desempenho das suas funçôes de condutores. $\mathrm{O}$ outro fator, mitificador também na minha opinião, é a ênfase dada a uma cultura da paz, como um apanágio do budismo, e apresentado com um forte sabor messiânico mesmo. Como se a história do budismo não fosse ela também permeada por episódios e momentos de violência... (Aliás, o que foi a história do Tibet, uma civilização feudal até meados do século XX, como disse o próprio Dalai Lama, senão a história de lutas entre diferentes reis!)

\section{CONCLUSÃO}

Se, como afirmou André Malraux, em uma frase que ficou célebre, "o século XXI ou será espiritual ou não será”, o enraizamento do budismo no Brasil poderá trazer importantes elementos de reflexão, num contexto em que a busca religiosa é marcada pela exigência de uma experiência pessoal, que destaque e enfatize a autonomia do indivíduo. Nesse sentido é preciso apontar também o fato de que o budismo apresenta elementos que, de certa forma, se coadunam em muito com a experiênáa contemporânea, ou pelo menos, entram em ressonância com ela. Destaco aqui a noção de interdependência, central ao budismo, quando pensada contra o pano de fundo de um momento históricode globalização, que nos aponta para a idéia de uma humanidade interligada, onde se torna cada vez mais assimilável ao senso comum que o que ocorre em uma parte do planeta afeta todo o resto.

O outro elemento seria a idéia de não-eu. Um conceito que, por mais 
estranho que pareça aos valores ocidentais, não se antepõe mas, antes, se coaduna com aqueles referidos ao de indivíduo como um valor de referência no quadro da ideologia ocidental moderna. Como afirma Tania Salem,

A imperiosa presença da alteridade para aceder a si não contradiz, de modo algum, o valor-indivíduo como valor estruturante por excelência. Pelo contrário, o reconhecimento da 'necessidade' de um 'outro' sofre tamanhas retraduçóes no mundo moderno, relativamente à forma que assume nos espaços tradicionais, que é plausível concluir que o indivíduo psicológico el ou a imprescindibilidade do 'outro' só adquirem sentido na configuração individualista. (Salem, 1992, p. 73).

A noção de não-eu longe de parecer algo bizarro teria, assim, de acordo com Salem, um terreno fértil na configuração individualista. Além disso, a psicanálise teria servido para desconstruir a idéia de um eu monolítico, encontrável após um processo de escavação. A psicanálise apontaria não para o processo de revelação de um enigma, o próprio eu, mas para a idéia desse eu como uma narrativa, no sentido de uma construção e organização da experiência e historia pessoais.

É aquilo que Salem denomina de "despossessão subjetiva", marcada pela idéia do inconsciente como manifestação exemplar da mesma e como um atributo constitutivo do indivíduo, pois de acordo com Gauchet e Swain, "A história da individualização é, de outro lado e necessariamente, a história de uma despossessão ou de uma destituição subjetiva" (Gauchete Swain, apud Salem, 1992, p. 71). Assim a noção budista de não-eu não seria algo tão estranho, uma vez que a psicanálise e a psicologia teriam preparado um terreno propício para ela. Interessante também que Giddens (2002) se refira a influência desses dois domínios de conhecimento e sua importância para a auto-reflexividade dos sujeitos contemporâneos.

No entanto, como Lévi-Strauss nos lembra:

Para o budismo, não existe o além; tudo se reduz a uma crítica radical, como a humanidade nunca mais se mostraria capaz de fazer, ao fim da qual o sábio cai 
numa recusa do sentido das coisas e dos seres: disciplina que abole o universo e que se suprime, ela própria, como religião. (Lévi-Strauss, 1996, p. 386)

E é essa dimensão crítica radical que talvez o budismo corra o risco de perder em sua ressignificação no Ocidente. Um risco oriundo de seus próprios praticantese líderes ao mitificá-lo como um remédio,como um método e, no final das contas, correndo o risco de ser assimilado como mais uma opção no espectro das terapias denominadas de auto-ajuda.

\section{REFERÊNCIAS}

ALVES, Daniel. Seres de sonho: percursos religiosos e práticas espirituais num centro budista ao sul do Brasil. Dissertação(Mestrado em Antropologia Social) - PPGAS/UFRGS, Porto Alegre, 2004.

CAROZZI,María Julia Novaera: a autonomia como religião.In: CAROZZI, María Julia (org.). A nova era no Mercosul. Petrópolis: Vozes, 1999.

COSTA, Jurandir Freire. O risco de cada um. Religião e sociedade. Rio de Janeiro, 21(2), p. 11-24, 2001.

GEERTZ, Clifford. Obras e vidas: o antropólogo como autor. Rio de Janeiro: UFRJ, 2002.

GIDDENS,Anthony. Modernidade e identidade. Rio de Janeiro: JorgeZahar, 2002.

LÉVI-STRAUSS,Claude. Tristes trópicos. São Paulo: Companhia das Letras, 1996

MADALENA GENZ, Antônio Carlos de. A música silenciosa do Darma: um estudo antropológico das práticas e representações de uma comunidade zen budista em PortoAlegre. Dissertação(Mestrado em AntropologiaSocial)

- PPGAS/UFRGS, Porto Alegre, 2005.

MORIYAMA ROSHI. Primeiros passos no zen. Porto Alegre: Bodigaya, 2001. 
ORO, Ari Pedro. Modernas formas de crer. Revista Eclesiástica Brasileira. Petrópolis: Rio de Janeiro, n. 225, p. 39-56, 1997.

SALEM, Tania. A “despossessão subjetiva”: dos paradoxos do individualismo. Revista brasileira de ciências sociais. n. 18, ano 7, p. 62-77, 1992.

STEIL, Carlos Alberto. Pluralismo, modernidade e tradição: transformações do campo religioso. Ciências sociais e religiāa. Porto Alegre, ano 3, n. 3, p. 115-129, 2001.

USARSKI, Frank. O dharma verde-amarelo mal-sucedido: um esboço da acanhada situação do budismo. Estud. av. [online]. Dec. 2004, vol.18, n.52 , p.303-320. Disponível em: <http://www.scielo.br/>.

ZIZEK, Slavoj. O culto da paixão descafeinada. Revista IHU On-line. São Leopoldo, ano 4, n. 91, p. 22-25, 2004. 